\title{
Predictive Technology Management for the Identification of Future Development Trends and the Maximum Achievable Potential Based on a Quantitative Analysis
}

\author{
Michael Fries*, Markus Lienkamp \\ Technical University of Munich, Department of Mechanical Engineering, Institute of Automotive Technology, 85748, Germany
}

\begin{tabular}{l} 
A R T I C L E I N F O \\
\hline Article history: \\
Received: 26 April, 2017 \\
Accepted: 11 June, 2017 \\
Online: 15 July, 2017 \\
\hline
\end{tabular}

Keywords:

Innovation management

Technology management

Technology assessment

Exponential growth

Logistic growth

Computational intelligence

Performance periods

Big data

Data mining

\begin{abstract}
A B S T R A C T
A company's ability to find the most profitable technology is based on a precise forecast of achievement potential. Technology Management (TM) uses forecasting models to analyse future potentials, e.g. the Gartner Hype Cycle, Arthur D. Little's technology lifecycle or McKinsey's S-curve model. All these methods are useful for qualitative analysis in the planning of strategic research and development (R\&D) expenses. In a new approach, exponential and logistic growth functions are used to identify and quantify characteristic stages of technology development. Innovations from electrical, mechanical and computer engineering are observed and projected until the year 2025. Datasets from different industry sectors are analysed, as the number of active Facebook users worldwide, the tensile yield point of flat bar steel, the number of transistors per unit area on integrated circuits, the fuel efficiency per dimension of passenger cars, and the energy density of Lithium-Ion cells. Results show the period of performance doubling and the forecast for the end of the technological achievement potential. The methodology can help to answer key entrepreneurial questions such as the search for alternatives to applied technologies, as well as identifying the risk of substitution technology.
\end{abstract}

\section{Introduction}

This paper is an extension of work originally presented at the IEEE International Conference on Industrial Engineering and Engineering Management, Indonesia in December 2016 [1]. The positive feedback from the audience helped in writing a more detailed mathematical description of the growth functions. Furthermore, the energy density of Li-Ion cells was analysed and added to the case studies, because of its relevance in future automotive driveline systems. The summary section includes an overview of the technology assessment for this newly added energy storage technology. An extended conclusion shows the influence of the approach introduced on strategical Technology Management. The newly added outlook paragraph discusses the benefits of a fundamental figure-based approach in combination with data mining for strategic decision making in research and development departments. With the help of a reporting system and individually derived performance indicators the future possibilities

${ }^{*}$ Corresponding Author: Michael Fries, Boltzmannstr. 15, 85748 Garching, Germany |Email: fries@ftm.mw.tum.de of making the right decisions will rise. In a big data driven, rapidly growing digital environment, new fields of application in many engineering branches will appear for the integration of the method.

Due to the rapid arrival of substitution technologies, companies are under growing pressure to make fast and sustainable decisions. In the past, even companies with market leader positions such as AOL, Kodak, Nokia and Grundig [2 ]have disappeared due to their reliance on outdated technology. According to methods such as the Gartner Hype Cycle and the technological lifecycle of Arthur D. Little [3], different stages of maturity describe the acceleration and deceleration of the achievable potential. The beginning and end of technological growth is qualitatively described by the S-curve model [4]. Figure 1 shows a qualitative example of technology substitution due to different growth phases. The objective of this paper is to forecast performance development and maximisation of the achievable potential. Therefore, logistic and exponential growth functions are used to quantify different growth patterns. This paper proposes a mathematical approach for technology forecasting and assessment. 


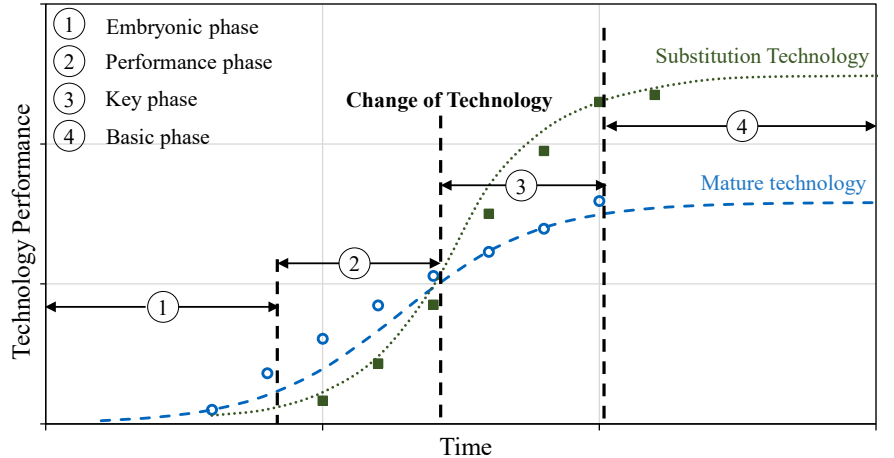

- Dataset Technology A

- - Logistic growth function technology A

- Dataset Technology B

Figure 1: S-curve model, Technology A is substituted by Technology B, the growth phases refer to Technology A [5].

\section{Methodology}

Data collected from different branches of industry are analysed with the logistic growth function from [6] and [7] to determine the growth phases. If the technology is in its performance phase, the data are fitted with an exponential growth function from [8] to identify the future performance development. The exponential growth is similar to the performance phase of the S-curve model. The overall shape of the S-curve follows the logistic growth function. Figure 2 displays the overlay of the performance phases of a mature technology and a substitution technology that leads to extended exponential performance growth.

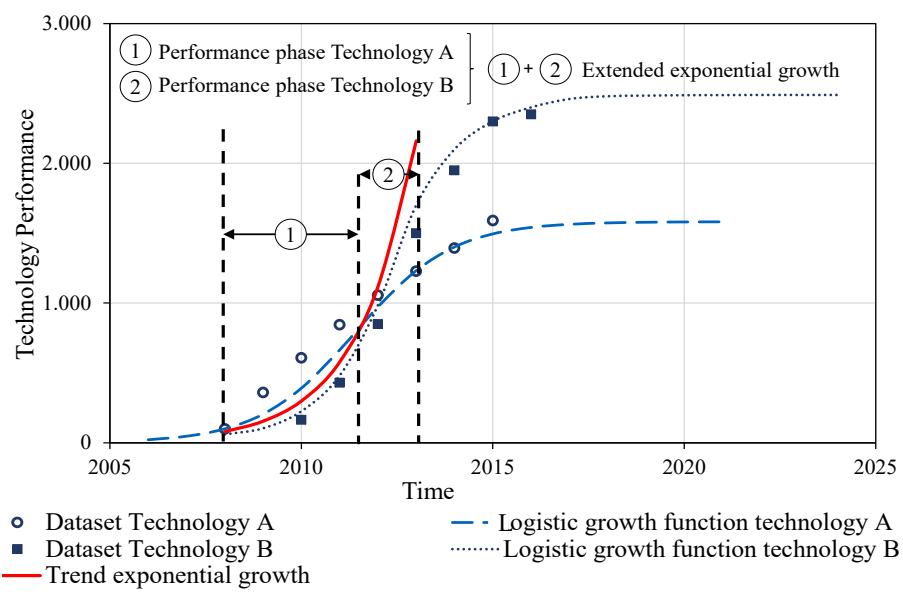

Figure. 2: Extended performance phase by the overlap of two logistic growth functions.

\subsection{Mathematical description of logistic growth}

Logistic growth is characterised by the growth coefficient $r$ changing over time $\mathrm{x}$, with $\mathrm{y}$ representing the performance of the technology and $\mathrm{K}$ the maximum value to be approximated, [6], [7]. Equation (1) gives the formula for the growth rate:

$$
\frac{\mathrm{d} y}{\mathrm{~d} x}=r y\left(1-\frac{y}{K}\right) .
$$

A positive slope in the growth rate leads to a continuous rise in technology performance. A negative slope of the growth rate corresponds to a slowdown in performance until the maximum value is approximated, Figure 3.

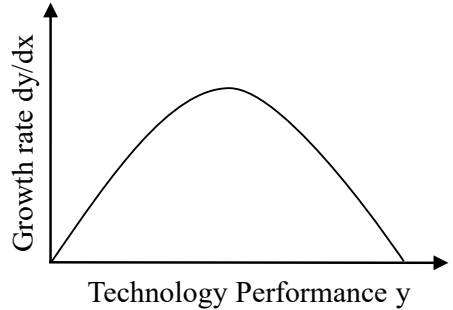

Figure 3: Slope of the technology growth rate

The logistic growth equation (2) follows from integrating (1) with the initial performance value $\mathrm{y}=\mathrm{y}_{0}$ at time $\mathrm{x}_{0}=0$ :

$$
y=\frac{K}{1+\left(\frac{K}{y_{0}}-1\right) e^{-r x}}
$$

The relative growth of the performance of a technology divided by the absolute performance $\mathrm{y}$ is linear relative to the absolute performance $y$. The linear equation can be derived from Figure 4 .

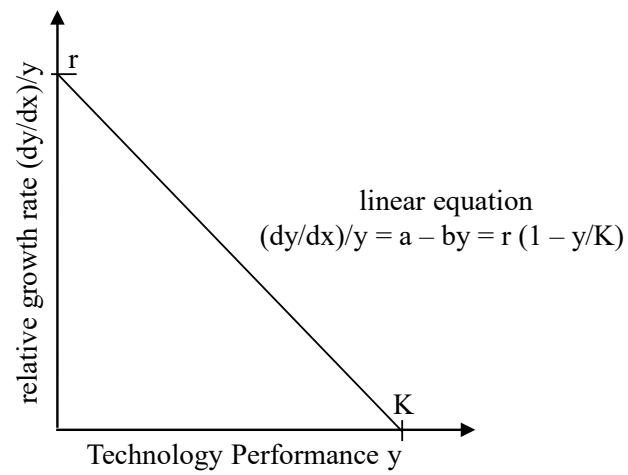

Figure 4: Determination of the growth coefficient $r$ and the max. value $\mathrm{K}$

Relative growth in relation to the absolute technology performance is described by the linear equation (3).

$$
\frac{(\mathrm{d} y / \mathrm{d} x)}{y}=a-b y
$$

The maximum value $\mathrm{K}$ and the growth coefficient $r$, from (2), can be determined by solving the linear equation (3).

$$
a-b y=r\left(1-\frac{y}{K}\right) .
$$

The growth rate $\mathrm{r}$ and the maximum value $\mathrm{K}$ follow from Equation (4):

$$
\begin{aligned}
r & =a \quad \text { and } \\
K & =\frac{a}{b} .
\end{aligned}
$$

Given the maximum value $\mathrm{K}$ and the growth coefficient $\mathrm{r}$, the logistic growth function from (2) is described completely (see Figure 5.) 


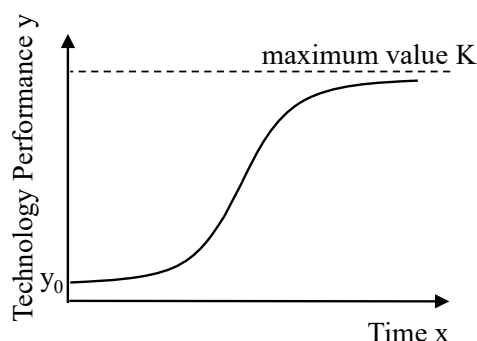

Figure 5: Logistic growth function from Equation (2)

\subsection{Mathematical description of exponential growth}

As shown in Figure. 2 the sum of the performance phases of multiple logistic growth functions leads to the continuous exponential growth of the technology performance. The effect is valid for many market developments.

Exponential growth is characterised by the growth coefficient $r$, the starting technology performance $\mathrm{y}_{0}$ in the embryonic phase and the time $x$ shown in (7) and [8]:

$$
\mathrm{y}=\mathrm{y}_{0} \mathrm{e}^{\mathrm{rx}}
$$

In exponential regression analysis, the existing data y are compared with the values calculated from the exponential curve equation (7). Equation (7) is logarithmised in Equation (8) to apply the method of least squares to the performance phase of a technology, [9].

$$
\ln (\hat{y})=\ln \left(y_{0} e^{r \hat{x}}\right)=r \hat{x}+\ln \left(y_{0}\right) .
$$

$$
\begin{aligned}
& V=\sum_{i=1}^{k}\left(y_{i}-\hat{y}_{i}\right)^{2} \text { and } \\
& V\left(r, \ln \left(y_{0}\right)\right)=\sum_{i=1}^{k}\left(\ln \left(y_{i}\right)-r x_{i}-\ln \left(y_{0}\right.\right.
\end{aligned}
$$

To determine the constants $\mathrm{r}$ and $\mathrm{y}_{0}$ as two unknowns with two equations, (10) is modified and the partial derivatives are set to zero to obtain the minimum.

Partially differentiating with respect to $\mathrm{y}_{0}$ :

$$
\begin{gathered}
\frac{\delta V\left(r, \ln \left(y_{0}\right)\right)}{\delta V\left(\ln \left(y_{0}\right)\right)}=2 \sum_{i=1}^{k}\left(\ln \left(y_{i}\right)-r x_{i}-\ln \left(y_{0}\right)\right)(-1)=0 \\
\rightarrow \quad \sum_{i=1}^{k} y_{i}=r \sum_{i=1}^{k} x_{i}+\ln \left(y_{0}\right) k
\end{gathered}
$$

$$
\begin{aligned}
& \rightarrow \quad \overline{\ln \left(y_{i}\right)}=r \bar{x}_{i}+\ln \left(y_{0}\right) \\
& \rightarrow \quad \overline{\ln \left(y_{0}\right)}=\overline{\ln \left(y_{i}\right)} r \bar{x}_{i}
\end{aligned}
$$

Partially differentiating with respect to $\mathrm{r}$ :

$$
\begin{aligned}
& \frac{\delta V\left(r, \ln \left(y_{0}\right)\right)}{\delta V\left(\ln \left(y_{0}\right)\right)}=2 \sum_{i=1}^{k}\left(\ln \left(y_{i}\right)-r x_{i}-\ln \left(y_{0}\right)\right)(-1)=0 \\
& \rightarrow \sum_{i=1}^{k}\left(x_{i} y_{i}\right)=r \sum_{i=1}^{k} x_{i}^{2}+\ln \left(y_{0}\right) \sum_{i=1}^{k} x_{i} \\
& \rightarrow \quad \overline{x_{i} \ln \left(y_{i}\right)}=r \overline{x_{i}^{2}}+\ln \left(y_{0}\right) \overline{x_{i}} \\
& \rightarrow r=\frac{\overline{x_{i} \ln \left(y_{i}\right)}-\overline{\ln \left(y_{i}\right)} \overline{x_{i}}}{\overline{x_{i}^{2}}-{\overline{x_{i}}}^{2}}
\end{aligned}
$$

\section{$\hat{y}$}

(7)

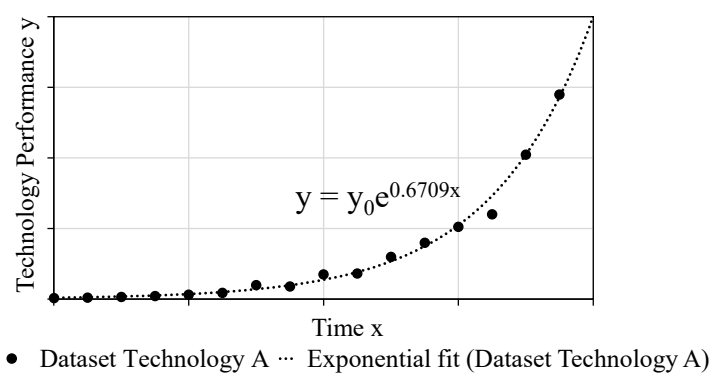

Figure 6: Determination of the growth coefficient $r$, in the graph $r=0.6709$, which corresponds to an annual technology growth of $67.09 \%$.

Given the growth coefficient $r$, the exponential growth function from (7) is described completely. The period during which the performance of technology doubles is calculated with the equations (19) and (20):

$$
\mathrm{x}=\ln \left(\frac{\mathrm{y}}{\mathrm{y}_{0}}\right) \frac{1}{\mathrm{r}}
$$

Doubling the performance implies $y / y_{0}=2$ :

$$
\ln (2)=0.69314718 \approx 0.70
$$

The fact that the natural logarithm of 2 equals 0.7 is the reason behind the 70-Rule, cf. (20), which is used in the automotive industry as a rule of thumb for rapid technology forecast and assessment. 


$$
\mathrm{x}=0.7 \frac{1}{\mathrm{r}}=70 \frac{1}{100 \mathrm{r}}
$$

In the example of Figure 6, the period of doubling of the technology performance is 70 divided by 67.09 , resulting in 1.04 years.

\section{Analysed cases}

In this section, the mathematical description of the technology performance is compared with actual data from technology undergoing continuous development. Five examples show the dependence of technology performance on growth functions. Each of the examples considered was individually analysed to identify logistic or exponential growth rates. The chosen examples are:

- Number of active Facebook users worldwide

- Tensile yield point of flat bar steel

- Number of transistors per unit area on integrated circuits

- Fuel efficiency per dimension of the VW Golf series

- Energy density of Li- Ion cells

\subsection{Number of active Facebook users worldwide}

Table I gives the number of active Facebook users from 2008 to 2015 [10]. The data considered for the analysis begins in 2008, when Facebook launched French, German and Spanish versions, leading to a surge in users worldwide [11].

Table 1: Annual Number Of Active Facebook Users Worldwide, [10]

\begin{tabular}{cl}
\hline \multicolumn{2}{c}{ Active Facebook users worldwide } \\
$\boldsymbol{x}$ & \multicolumn{1}{c}{$\boldsymbol{y}$} \\
\hline Quarter / Year & Number in millions \\
\hline Q4 / 2008 & 100 \\
Q4 / 2009 & 360 \\
Q4 / 2010 & 608 \\
Q4 / 2011 & 845 \\
Q4 / 2012 & 1,056 \\
Q4 / 2013 & 1,228 \\
Q4 / 2014 & 1,393 \\
Q4 / 2015 & 1,591 \\
\hline
\end{tabular}

Figure 7 shows the determination of the growth coefficient $r=$ 0.791 and the maximum value $\mathrm{K}=1,582$ using the linear equation (4).

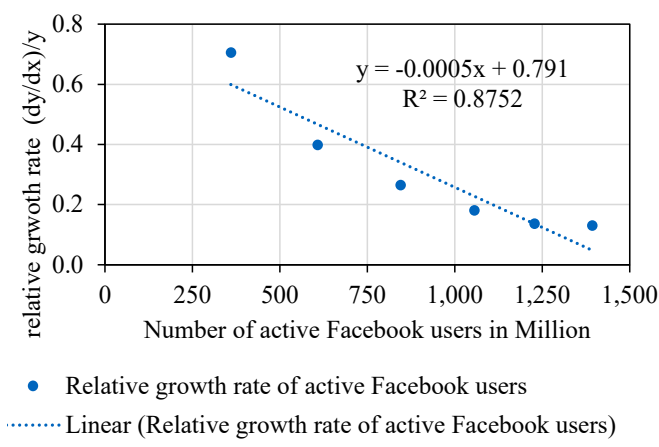

Figure 7: Relative growth rate in relation to the absolute technology performance
Figure 8 displays the S-curve including the coefficients of the logistic growth from equation (2).

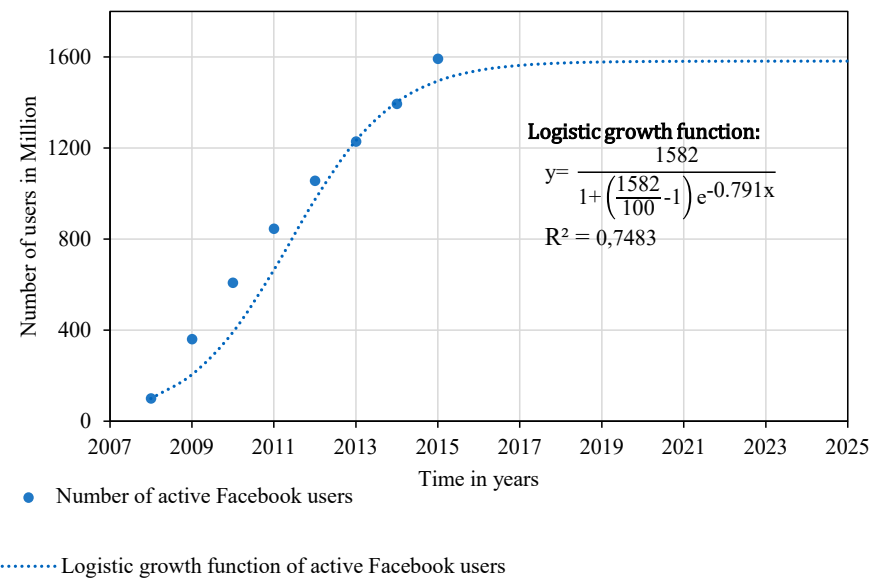

Figure 8: Active Facebook users worldwide, described by logistic growth.

Conclusion: The relative growth rate of active Facebook users worldwide slowed down after the years 2009 and 2010. People without internet access represent the sleeping potential of the technology performance. Despite the slowdown in user growth, no substitute technology has been identified thus far.

\subsection{Tensile yield point of flat bar steel}

The tensile yield point is a material parameter and designates the tension limit of non-permanent plastic deformation in the material. Table II gives an overview of the technological progression of the achievement potential.

Table 2: Tensile yield point of flat bar steel [12]

\begin{tabular}{cc}
\hline \multicolumn{2}{c}{ Tensile yield point of flat bar steel } \\
$\boldsymbol{x}$ & $\boldsymbol{y}$ \\
\hline Year & $\begin{array}{c}\text { Tensile yield point in } \\
\text { MPa }\end{array}$ \\
\hline 1926 & 355 \\
1955 & 460 \\
1965 & 690 \\
1972 & 890 \\
1980 & 960 \\
1996 & 1,100 \\
2013 & 1,200 \\
\hline
\end{tabular}

Figure 9 shows the linear equation of the relative growth rate in relation to the absolute technology performance. Solving the linear Equation with Equation (4), the values $\mathrm{r}$ and $\mathrm{K}$ are found to be equal to $\mathrm{r}=0.0411, \mathrm{~K}=1,500$.

Figure 10 displays the logistic growth function adapted from $r=$ 0.0411 to 0.03 due to a minimum set of data pairs relative to the period. 
M. Fries et al. / Advances in Science, Technology and Engineering Systems Journal Vol. 2, No. 3, 1042-1049 (2017)

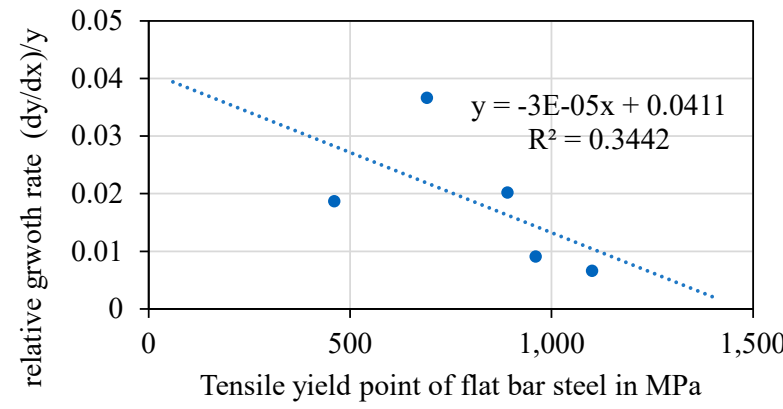

- Relative growth rate of tensile yield point of flat bar steel

........ Linear (Relative growth rate of tensile yield point of flat bar steel)

Figure 9: Relative growth rate in relation to the absolute technology performance of flat bar steel

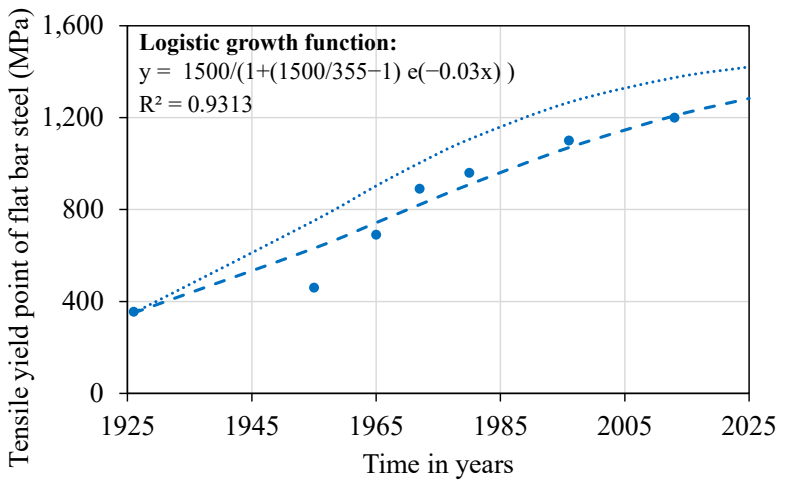

- Tensile yield point of flat bar steel

….... Logistic growth function of tensile yield point of flat bar steel with $\mathrm{r}=0.0411$

- - - Logistic growth function of tensile yield point of flat bar steel with $\mathrm{r}=0.03$

Figure 10: Logistic growth function of the tensile yield point of flat bar steel with adapted growth rate from 0.0411 to 0.03 .

Conclusion: The tensile yield point of flat bar steel from [12] has left the performance phase and is now in its key phase.

\subsection{Number of transistors per unit area on integrated chips}

The number of transistors per unit area on integrated circuits is designated as the integration density, [13]. In 1965 Gordon Moore, Co-founder of Intel, predicted that the integration density will double every 12 to 24 months. This observation is known as Moore's law. In [14] the executive Vice President of Intel William M. Holt, showed that there are leading technology options in the near future beyond complementary metal-oxide-semiconductors (CMOS) that can advance the exponential prediction of Gordon Moore. Table III depicts the integration density development.

Table 3: Overview of Integration density development on integrated chips [13]

\begin{tabular}{rcc}
\hline $\begin{array}{c}\text { Number of transistors per unit area on integrated circuits } \\
\text { (integration density) }\end{array}$ \\
\cline { 2 - 3 } Processor & \multicolumn{1}{c}{ Year } & \multicolumn{1}{c}{ Integration density } \\
\hline Intel 4004 & 1971 & 2,300 \\
Intel 8008 & 1972 & 3,500 \\
\hline
\end{tabular}

\begin{tabular}{|c|c|c|}
\hline \multicolumn{3}{|c|}{$\begin{array}{l}\text { Number of transistors per unit area on integrated circuits } \\
\text { (integration density) }\end{array}$} \\
\hline \multirow{2}{*}{ Processor } & $x$ & $y$ \\
\hline & Year & Integration density \\
\hline Intel 8080 & 1974 & 4,500 \\
\hline Intel 8088 & 1979 & 29,000 \\
\hline Intel 80286 & 1982 & 134,000 \\
\hline Intel 80386 & 1985 & 275,000 \\
\hline Intel 80486 & 1989 & $1,180,235$ \\
\hline Pentium & 1993 & $3,100,000$ \\
\hline AMD K5 & 1996 & $4,300,000$ \\
\hline Pentium II & 1997 & $7,500,000$ \\
\hline Pentium 4 & 2000 & $42,000,000$ \\
\hline AMD K8 & 2003 & $105,900,000$ \\
\hline Itanium 2 with $9 \mathrm{MB}$ cache & 2004 & $592,000,000$ \\
\hline Cell & 2006 & $241,000,000$ \\
\hline Core 2 Duo & 2006 & $291,000,000$ \\
\hline Six core opteron 2400 & 2009 & $904,000,000$ \\
\hline 8-core Xeon nehalem-ex & 2010 & $2,300,000,000$ \\
\hline 8-core Itanium Poulson & 2012 & $3,100,000,000$ \\
\hline Xbox One main SoC & 2013 & $5,000,000,000$ \\
\hline 22-core Xeon Broadwell-E5 & 2016 & $7,200,000,000$ \\
\hline
\end{tabular}

Figure 11 shows that the mathematical determination of the growth coefficient $r$ and the maximum value $K$ with (4) is not possible. The reason is the continuous relative growth rate of the integration density, which has not slowed down over the years.

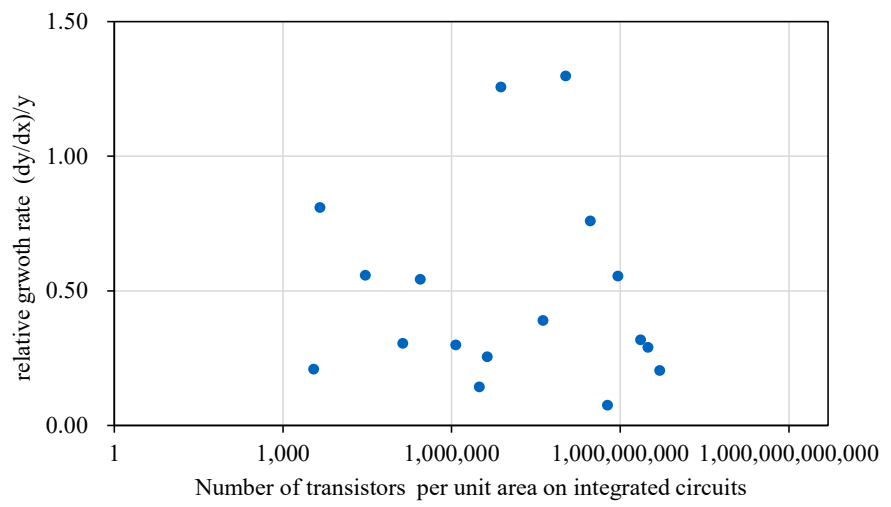

- Integration density

Figure 11: Relative growth rate over a number of transistors per unit area on integrated circuits.

According to [14] the exponential growth of the integration density is based on the substitution of the process and the device technology. This leads to an extension of the performance phase. Figure 12 gives an overview of the innovations leading to the performance increase. The exponential fit uses the method of least squares from [9]. 


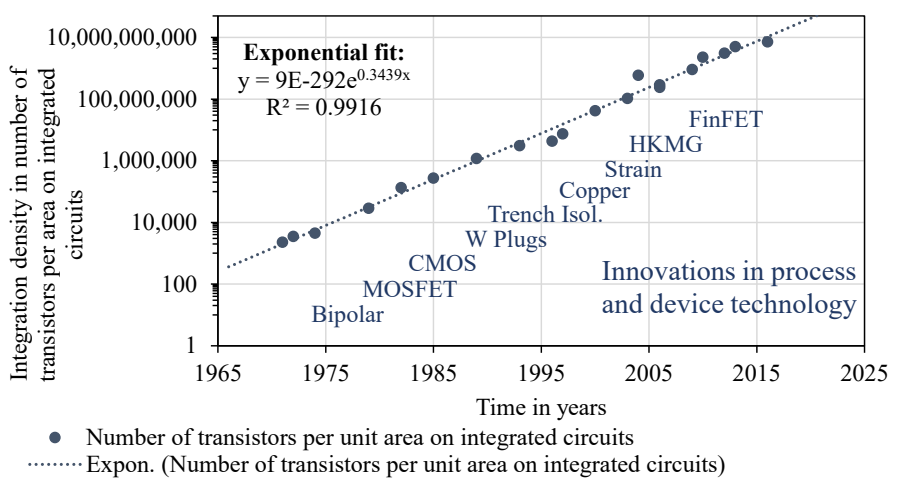

Figure 12: Exponential growth of integration density on logarithmic scale

Conclusion: The trend demonstrated in Figure 12 shows the substitution of process and device technology leading to an extended performance phase. The time for doubling the number of transistors per unit area is around 2.04 years, taking into account an annual growth rate of $34.39 \%$. Moore's prediction from 1965 is still valid.

\subsection{Fuel Efficiency per dimension of VW Golf series}

The automotive industry faces new challenges such as carbon dioxide $\left(\mathrm{CO}_{2}\right)$ legislation in Europe with an upper limit of $95 \mathrm{~g} / \mathrm{km}$ for every newly licensed passenger car from the beginning of 2020 [20]. In the United States, the Environmental Protection Agency (EPA) tightened the regulatory programme to 225 gram $\mathrm{CO}_{2}$ per mile for passenger cars [21] this year. As a contrary trend, vehicle dimensions (length, width, height) are still increasing. Table V shows the fuel efficiency in kilometre per litre and the growing dimensions of the VW Golf series since 1976. That year, the VW Golf had its start of production (SOP) with its first diesel engine.

Table 4: Fuel efficiency Per vehicle dimensionS of VW Golf series I to Vii [22], [23], [24]

\begin{tabular}{lccccccc}
\hline \multicolumn{7}{c}{ Fuel efficiency per vehicle dimension of VW Golf series (diesel } \\
engine) \\
\cline { 2 - 8 } Series & $\begin{array}{c}\text { Year } \\
\text { of } \\
\text { SOP }\end{array}$ & $\begin{array}{c}1 / 100 \\
\mathrm{~km}\end{array}$ & $\mathrm{~km} / \mathrm{l}$ & $\mathrm{hp}$ & $\mathrm{ccm}$ & $\begin{array}{c}l w h \\
\text { in } \mathrm{m}^{3}\end{array}$ & $\begin{array}{r}(\mathrm{km} / \mathrm{l}) \\
\mathrm{m}^{3}\end{array}$ \\
\hline Golf I & 1976 & 5 & 20.0 & 50 & 1,500 & 8.4 & 167 \\
Golf II & 1983 & 5 & 20.0 & 54 & 1,577 & 9.4 & 188 \\
Golf III & 1996 & 5 & 20.0 & 110 & 1,896 & 9.7 & 194 \\
Golf IV & 1997 & 4.9 & 20.4 & 110 & 1,896 & 10.4 & 211 \\
Golf V & 2007 & 4.5 & 22.2 & 105 & 1,896 & 11.0 & 244 \\
Golf VI & 2009 & 4.1 & 24.4 & 105 & 1,598 & 11.0 & 269 \\
Golf VII & 2012 & 3.8 & 26.3 & 105 & 1,598 & 11.1 & 292 \\
\hline
\end{tabular}

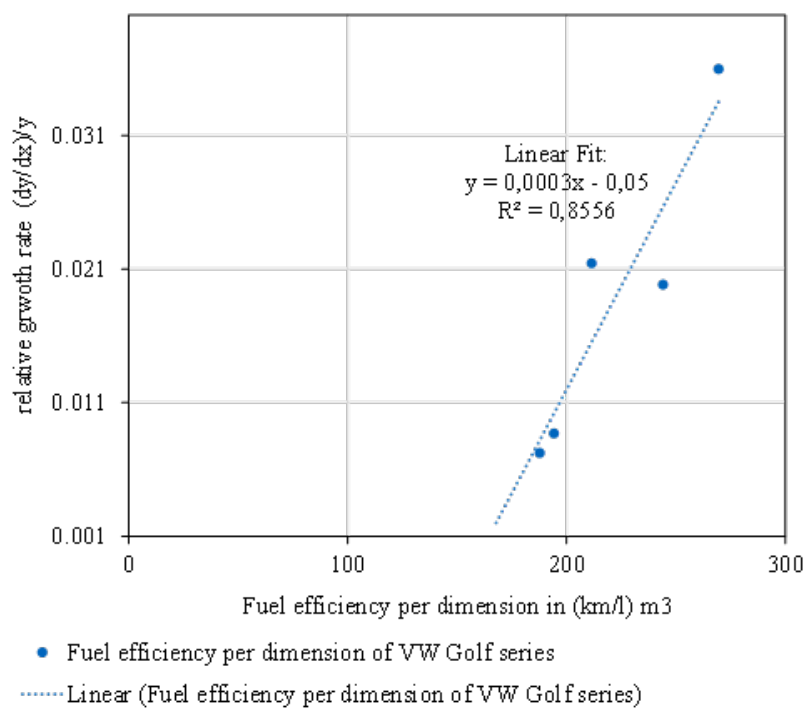

Figure 14 displays the exponential growth of the fuel efficiency per dimension. The coefficient of determination shows a correspondence of $\mathrm{R}^{2}=0.9062$.

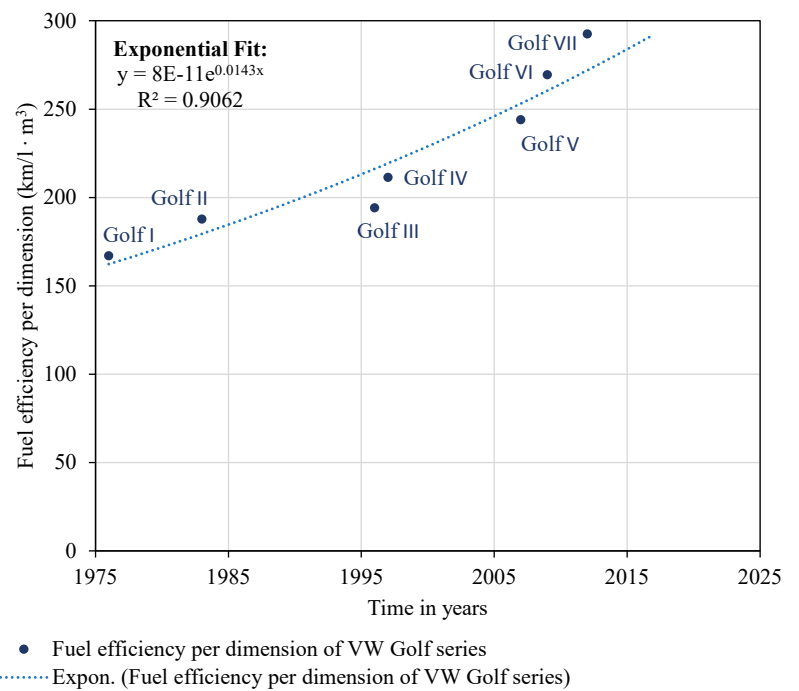

Figure 14: Exponential growth of fuel efficiency per vehicle dimension of VW Golf series.

Conclusion: The fuel efficiency per vehicle dimension of the VW Golf series is exponentially increasing. The fuel efficiency of successive generations of vehicles has improved despite the increasing vehicle dimensions (length, width and height). The substitution of technologies in each vehicle generation has caused this effect, leading to the extension of the performance phase. The exponential annual growth rate determined amounts to $1.43 \%$. The 70 rule predicts a doubling of performance in 48.95 years.

\subsection{Energy density of Li-Ion cells}

Over the next ten years, Li-Ion cells will not be only used in stationary and portable applications. According to [20], about $50 \%$ to $70 \%$ will be used in electro-mobility. 
Table 5: Energy density of Li-ion cells with 18650 format [21], [22], [23] and [24]

\begin{tabular}{|c|c|}
\hline \multicolumn{2}{|c|}{ Energy Density of LI-Ion cells } \\
\hline$x$ & $y$ \\
\hline Year & Density in $\mathrm{Wh} / \mathrm{kg}$ \\
\hline 1992 & 100 \\
\hline 1996 & 110 \\
\hline 1998 & 130 \\
\hline 2000 & 140 \\
\hline 2001 & 150 \\
\hline 2002 & 160 \\
\hline 2004 & 180 \\
\hline 2005 & 200 \\
\hline 2009 & 210 \\
\hline 2010 & 230 \\
\hline 2012 & 270 \\
\hline
\end{tabular}

Figure 15 displays the relative growth of Li-Ion cells compared to technology performance in $\mathrm{Wh} / \mathrm{kg}$. The linear equation from (4) cannot be solved, as the relative growth rate does not slow down, while the growth coefficient $r$ for logistic growth and the maximum value are not identified. The reason is the ongoing exponential growth.

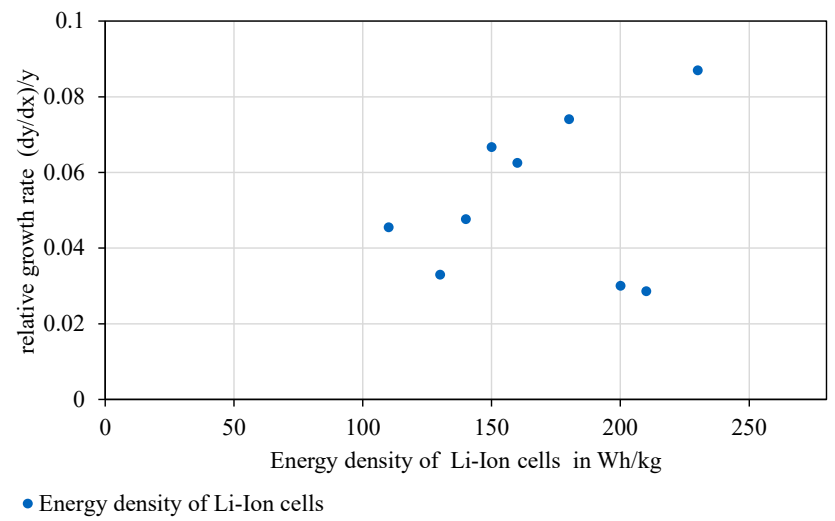

Figure 15: Relative growth rate over energy density of Li-Ion cells

In Fig 16, the exponential fit shows a correspondence of 0.976 for the coefficient of determination $\mathrm{R}^{2}$. Data points were matched with the names of cells from Sanyo/Panasonic.

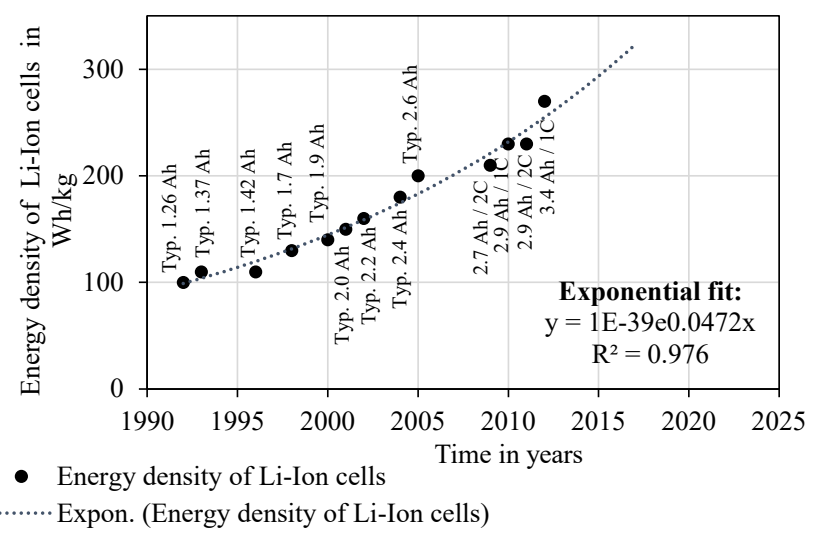

Fig 16: Exponential growth of energy density of Li-Ion cells.
Conclusion: The energy density of Li-Ion cells is still in its performance phase. The substitution of the material composition of anode, cathode or separator leads to the extension of the exponential performance. The ongoing exponential growth has an annual growth rate of $4.72 \%$. Using the 70 rule, a performance doubling of the energy density in Li-Ion cells can be expected in 14.83 years. The Fraunhofer Institute for System and Innovation Research predicts that post-Li-Ion technology can reach a performance of up to $500 \mathrm{Wh} / \mathrm{kg}$ on the level of individual cells [20].

\section{Summary and Conclusion}

In response to the rising demand of companies to make reliable decisions based on TM and technology road maps, this paper proposed a mathematical approach for technology forecasting and assessment. The benefit for academics and industry is a quantitative method for identifying the level of technology maturity. The mathematical description of achievement potential using the logistic growth function has been introduced and compared with the S-curve model. Table VI gives an overview of the analysed case studies.

\begin{tabular}{ccc} 
& Table 6: Overview of results \\
\hline Overview of results & $\begin{array}{c}\text { Phase in the } \\
\text { S-curve } \\
\text { model }\end{array}$ & $\begin{array}{c}\text { Period of } \\
\text { performance } \\
\text { doubling in years }\end{array}$ \\
\hline Facebook user & Key phase & - \\
$\begin{array}{c}\text { Tensile yield point } \\
\text { of flat bar steel } \\
\text { Number of } \\
\text { transistors per unit } \\
\text { area on integrated } \\
\text { chips }\end{array}$ & Key phase & - \\
$\begin{array}{c}\text { Fuel efficiency per } \\
\text { dimension of VW } \\
\text { Golf series }\end{array}$ & $\begin{array}{c}\text { Performance } \\
\text { phase }\end{array}$ & 48.95 \\
$\begin{array}{c}\text { Energy density of } \\
\text { Li-Ion cells }\end{array}$ & $\begin{array}{c}\text { Performance } \\
\text { phase }\end{array}$ & 14.83 \\
\hline
\end{tabular}

The 70 rule for deriving the period of performance doubling, is a method for forecasting the technological development in its performance phase. Both rules are applied to a series of example cases. The results clearly show that the key technologies such as the number of transistors per unit area on integrated chips, the fuel efficiency per dimension and the energy density of Li-Ion cells are still growing exponentially.

\section{Outlook}

Further investigation and discussion is needed to clarify whether integrating other relevant aspects that influence the technology performance forecast is meaningful. Firstly, an analysis must clarify which aspects can be considered as relevant for technological growth besides improvements in process and device technology: For instance, it is generally assumed that interdependencies exist between the improvement of the growth rate and aspects such as the financial environment and its 


\section{Fries et al. / Advances in Science, Technology and Engineering Systems Journal Vol. 2, No. 3, 1042-1049 (2017)}

characteristics such as resources, organisational structure and corporate culture. Secondly, the renewal time, during which the technology performance improves, must be measured precisely. It influences the shape of the S-curve model and can lead to transitions between the technological growth phases. Further possibilities, such as data mining and deriving key indicators for research and development topics, e.g. more precise online map data [25], lead to well-grounded decisions in strategic technology management. Technology road maps based on fundamental figures will be more successful in the long run. One of the next steps is the integration of automated search algorithms to gain a larger database for more accurate predictions of growth rates. An approach based on big data can help to gather more information over a shorter period. The future management of research and development will lead to a new dimension of decision-making tools.

\section{Contributions}

Special thanks go to Mr. Claudio Sutter, who helped to collect raw data for further investigation into technological growth during his master's thesis in 2015.

\section{Acknowledgement}

This work was presented at the IEEE 2016 International Conference on Industrial Engineering and Engineering Management (IEEM16)

\section{References}

[1] M. Fries, M. Lienkamp: "Technology Assessment Based on Growth Functions for Prediction of Future Development Trends and the Maximum Achievable Potential", in IEEE Proceedings of 2016 International Conference on Industrial Engineering and Engineering Management, Indonesia, 2016. https://doi.org/10.1109/IEEM.2016.7798140

[2] J. Höhmann, "New tools for strategists," Harvard Business Manager Germany, vol. 6/2014, June 2014.

[3] M. Steinert, L. Leifer, "Scrutinizing Gartner's Hype Cycle Approach", in IEEE Proccedings of Technology Management for Global Economic Growth, 2010.

[4] G. Schuh, D. Guo and M. Wellensiek, "Approach for the Measurement of Technology Management Performance and Value", in IEEE Proceedings of Portland International Conference on Management of Engineering and Technology, 2013.

[5] G. Schuh, S. Klappert, Technology Management - Handbook Production and Management 2. Berlin, Heidelberg: Springer Verlag, 2011, pp.43 ff.

[6] P. Blanchard, P. L. Devaney, G. R. Hall, Differential Equations. Boston, Cengage Learning, 2012.

[7] P. Blanchard, P. Cummings: Course Math226.1x Introduction to Differential Equations. Module 1, Video 6 \& 7. Boston University, https://courses.edx.org, last call 26.04.2015.

[8] T. Wihler, Mathematics for Biology, Mathematical Institute, University of Bern, 2009, pp. 50-52.

[9] University of Leipzig, "Regression analysis", Informatics. http://www.stksachs.uni-

leipzig.de/tl_files/media/pdf/lehrbuecher/informatik/Regressionsanalyse.pd $\mathrm{f}$, last call 01.06 .2016

[10] Internet Live Stats, Facebook active users, http://www.internetlivestats.com/watch/facebook-users, statistics analysed from statista.com, last call 10.06.2016.

[11] M. Musgrove, "Facebook passes MySpace with global boost", The Washington Post - Technology, June 2008.
[12] Salzgitter Flachstahl GmbH, "Moderne Stahlvielfalt mit Blickpunkt Zukunft was die Automobilindustrie erwarten darf" (in German). Hannover Messe, 2013.

[13] T. Häberlein, Computer Engineering. Wiesbaden: Vieweg + Teubner Verlag, 2011, pp. 2-5.

[14] W. M. Holt, "Moore's law: A Path Going Forward", in IEEE Proceedings of International Solid-Stat Circuits Conference, Februrary 2016.

[15] European Parliament and Council of the European Union, "Setting emissions performance for standards for new passenger cars as part of the Community's integrated approach to reduce $\mathrm{CO}_{2}$ emissions from light-duty vehicles", Regulation (EC) No 443/2009, April 2009.

[16] United States Environmental Protection Agency, "EPA and NHTSA finalize historic National Program to reduce Greenhouse Gases and Improve Fuel Economy for Cars https://www3.epa.gov/otaq/climate/regulations/420f10014.pdf, April 2010.

[17] Autodata, "Volkswagen - Golf VII", http://www.autodata.net/de/?f=showCar\&car id=17891, last call 01/06/2016.

[18] Autoscout24, "Golf - 2008 until today", http://autokatalog.autoscout24.de/vw/golf-vi-2008-heute/, last cal 01/06/2016.

[19] Autobild, "The real Volkswagen - VW Golf II 1983 - 1991/92", "http://www.autobild.de/artikel/vw-golf-ii-1983-1991-92--44133.html, last call $01 / 06 / 2016$

[20] Fraunhofer Institute of System and Innovation Research, Roadmap energy storage for electromobility 2030, December 2015.

[21] A. Kinoshita, "Development of Sanyo Li/Ion Batteries", Sanyo Electric Co., Ltd, 2009.

[22] SANYO: Cell Type UR18650ZTA, Specifications, June 2010

[23] PANASONIC: Cell Type NCR18650PD, Specifications, February 2010, pp. 5-7.

[24] PANASONIC: Cell Type NCR18650B, Specifications, January 2013, pp. 57.

[25] M. Fries, M. Kruttschnitt, M. Lienkamp: "Multi-Objective Optimization of a Long-Haul Truck Hybrid Operational Strategy And a Predictive Powertrain Control System", in IEEE Proceedings of the 12th International Conference on Ecological Vehicles and Renewable Energies, Monaco Monte Carlo, 2017. https://doi.org/10.1109/EVER.2017.7935872 